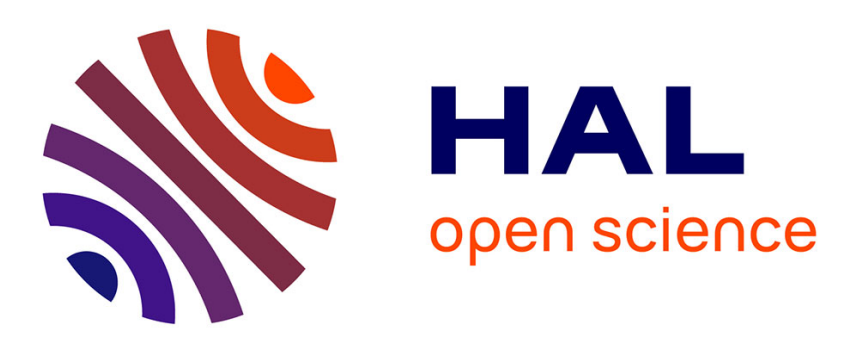

\title{
Ruthenium-Catalyzed C-H Arylation and Alkenylation of Furfural Imines with Boronates
}

Filipa Siopa, Valérie-Anne Ramis Cladera, Carlos Alberto Mateus Afonso, Julie Oble, Giovanni Poli

\section{To cite this version:}

Filipa Siopa, Valérie-Anne Ramis Cladera, Carlos Alberto Mateus Afonso, Julie Oble, Giovanni Poli. Ruthenium-Catalyzed C-H Arylation and Alkenylation of Furfural Imines with Boronates. European Journal of Organic Chemistry, 2018, 2018 (44), pp.6101-6106. 10.1002/ejoc.201800767 . hal01975395

\section{HAL Id: hal-01975395 \\ https://hal.sorbonne-universite.fr/hal-01975395}

Submitted on 9 Jan 2019

HAL is a multi-disciplinary open access archive for the deposit and dissemination of scientific research documents, whether they are published or not. The documents may come from teaching and research institutions in France or abroad, or from public or private research centers.
L'archive ouverte pluridisciplinaire HAL, est destinée au dépôt et à la diffusion de documents scientifiques de niveau recherche, publiés ou non, émanant des établissements d'enseignement et de recherche français ou étrangers, des laboratoires publics ou privés. 


\title{
Ruthenium-Catalyzed C-H Arylation and Alkenylation of Furfural Imines with Boronates
}

\author{
Filipa Siopa, ${ }^{[a, b]}$ Valérie-Anne Ramis Cladera, ${ }^{[a]}$ Carlos Alberto Mateus Afonso ${ }^{[b]}$ Julie Oble, ${ }^{*[a]}$ and \\ Giovanni Poli ${ }^{\star[a]}$
}

\begin{abstract}
A} \mathrm{Ru}(0)$-catalyzed direct $\mathrm{C}-\mathrm{H}$ arylation and alkenylation of furfural imines with aryl- or alkenyl-boronates, in the presence of benzylideneacetone as a sacrificial hydride acceptor, is disclosed. This reaction provides access, after hydrolysis, to C3-arylated or vinylated furfural derivatives, and thus valorizes these relevant building-blocks obtained from lignocellulosic biomass. This approach involving $\mathrm{C}-\mathrm{H}$ activation by a $\mathrm{Ru}(0) / \mathrm{Ru}(\mathrm{II})$, cycle offers several advantages, notably simple, mild and neutral reaction conditions.
\end{abstract}

\section{Introduction}

Over the past decade, environmentally benign organic reactions featuring the direct functionalization of non-activated $\mathrm{C}-\mathrm{H}$ bonds have emerged to maximize the step- as well as the atom-economy of a synthetic route. ${ }^{1]}$ Furthermore, the implementation of these catalytic $\mathrm{C}-\mathrm{H}$ transformations on renewable feedstocks is becoming an attractive strategy that paves the way toward greener chemical supplies by merging two eco-compatible approaches. In particular, lignocellulosic biomass valorization has recently received significant attention as an alternative to the shortage of petroleum resources, for the sustainable production of chemicals and bio-fuels. ${ }^{[2]}$ Furfural $\mathbf{1}^{[3]}$ and 5-(hydroxymethyl)furfural (HMF) $2,{ }^{[4]}$ readily obtained by cyclodehydration of abundant natural carbohydrate materials, are among the most important unsaturated bulk available from biomass. Thus, efficient transformations of $\mathbf{1}$ and $\mathbf{2}$ into more complex chemicals and fuels, ${ }^{[5,6]}$ as well as applications of these molecules in the fields of polymers ${ }^{[7]}$ and pharmaceuticals, ${ }^{[4]}$ represent highly desirable projects. Some transition metal (TM)catalyzed direct $\mathrm{C}-\mathrm{H}$ functionalizations of furfural have been reported. Most of these studies addressed the functionalization at the C5 position of the furan ring (arylation, ${ }^{[8]}$ alkylation, ${ }^{[9]}$ alkenylation $^{[10]}$ and alkynylation ${ }^{[11]}$ ) (Scheme 1a). In contrast, C3$\mathrm{H}$ functionalization via directing groups that force the natural $\mathrm{C5}$ preference has been much less studied (Scheme 1b). ${ }^{[12]}$ For our part, we recently reported a directed $\mathrm{Ru}(0)$-catalyzed addition of vinylsilanes (Murai reaction) to furfural imines, leading to C3alkylated furfurals (Scheme 1c). ${ }^{[13]}$ We now describe the $\mathrm{Ru}(0)$ catalyzed $^{[14]} \mathrm{C} 3-\mathrm{H}$ arylation and alkenylation of furfural imines

[a] Dr. F. Siopa, V-A. Ramis Cladera, Dr. J. Oble, Prof. Dr. G. Pol Sorbonne Université, Faculté des Sciences et Ingénierie, CNRS, Institut Parisien de Chimie Moléculaire, IPCM, 4 place Jussieu, 75005 Paris, France

E-mail: julie.oble@sorbonne-universite.fr, giovanni.poli@ sorbonneuniversite.fr ; http://www.ipcm.fr/Presentation,276

[b] Dr. F. Siopa, Prof. Dr. C. A. M. Afonso

Research Institute for Medicines (iMed.ULisboa), Faculty of Pharmacy, Universidade de Lisboa, Av. Prof. Gama Pinto, 1649-003 Lisboa, Portugal

Supporting information for this article is given via a link at the end of the document. with boronate derivatives (Scheme 1d). The adopted protocol takes inspiration from the reported $\mathrm{Ru}(0)$-catalyzed $\mathrm{C}-\mathrm{H}$ arylations (or alkenylations) of aryl-ketones, ${ }^{[15]}$ amides, ${ }^{[16}$ ] nitriles ${ }^{[17]}$ and imines, ${ }^{[18]}$ which make use of a sacrificial hydride scavenger to prevent the reduction of the directing group by the in situ generated $\mathrm{Ru}-\mathrm{H}$ species. Pinacolone is the most common hydride acceptor, while benzylideneacetone (BA) has been recently used for the reaction with aryl-imines. ${ }^{[18]}$ The optimization and the scope of this $\mathrm{C}-\mathrm{H}$ activation-based transformation of furfural imines are here summarized.

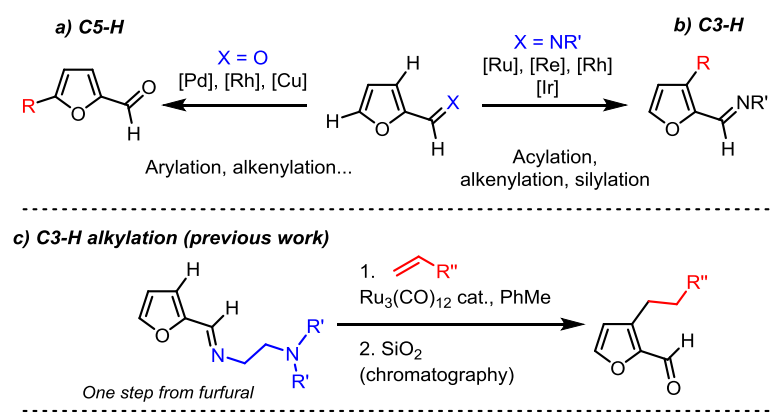

d) C3-H arylation and alkenylation: this work

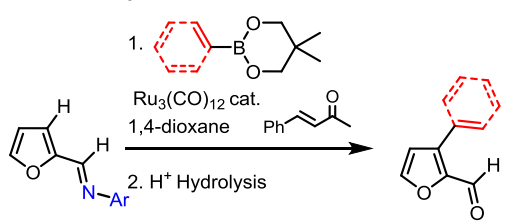

Scheme 1. TM-catalyzed direct $\mathrm{C}-\mathrm{H}$ functionalizations of furfural derivatives.

\section{Results and Discussion}

We started our study by adopting the same conditions as recently reported by Szostak for the Ru-catalyzed $\mathrm{C}-\mathrm{H}$ bond arylation of aromatic imines with arylboronates, ${ }^{[18]}$ namely: 5 mol\% of $\mathrm{Ru}_{3}(\mathrm{CO})_{12}, \quad 1.5$ equiv. of phenylboronic acid neopentylglycol ester (PhBnep) and 1.1 equiv. of $\mathrm{BA}$, in toluene at $125^{\circ} \mathrm{C}$ (oil bath), in sealed tube. A series of furfural-imines 3a-c, readily prepared in one-step from furfural 1 (see $\mathrm{SI}$ ), was examined under the above conditions (Scheme 2). On the one hand, the N,N'-bidentate imine $\mathbf{3 a}$, which previously showed satisfactory results in the Murai reaction (Scheme 1b) ${ }^{[13]}$ did not furnish the desired product, whereas benzyl-imine $\mathbf{3 b}$ displayed a low reactivity. On the other hand, use of $p$-methoxyphenylimine (PMP-imine) $3 c$ lead to the desired C3-phenylated imine $4 \mathbf{c a}^{[19]}$ in $43 \%$ NMR yield. 


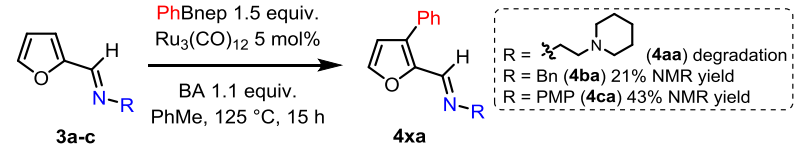

Scheme 2. Ru-catalyzed C3-phenylation of imines 3a-c.

Following this promising result, we carried on the optimization with the PMP-imine $3 c$ testing different solvents and temperatures (Table 1). While the reaction carried out in toluene at 125 or $140{ }^{\circ} \mathrm{C}$ led to similar NMR yields as before, the use of 1,4-dioxane at $130{ }^{\circ} \mathrm{C}$ gave $55 \%$ NMR yield of 4 ca (entries 1-4). An experiment realized at $140{ }^{\circ} \mathrm{C}$ in pinacolone as both the solvent provided an inferior result (entry 5 ).

Table 1. Ru-catalyzed C3-phenylation of aryl imines 3c-h. ${ }^{[a]}$

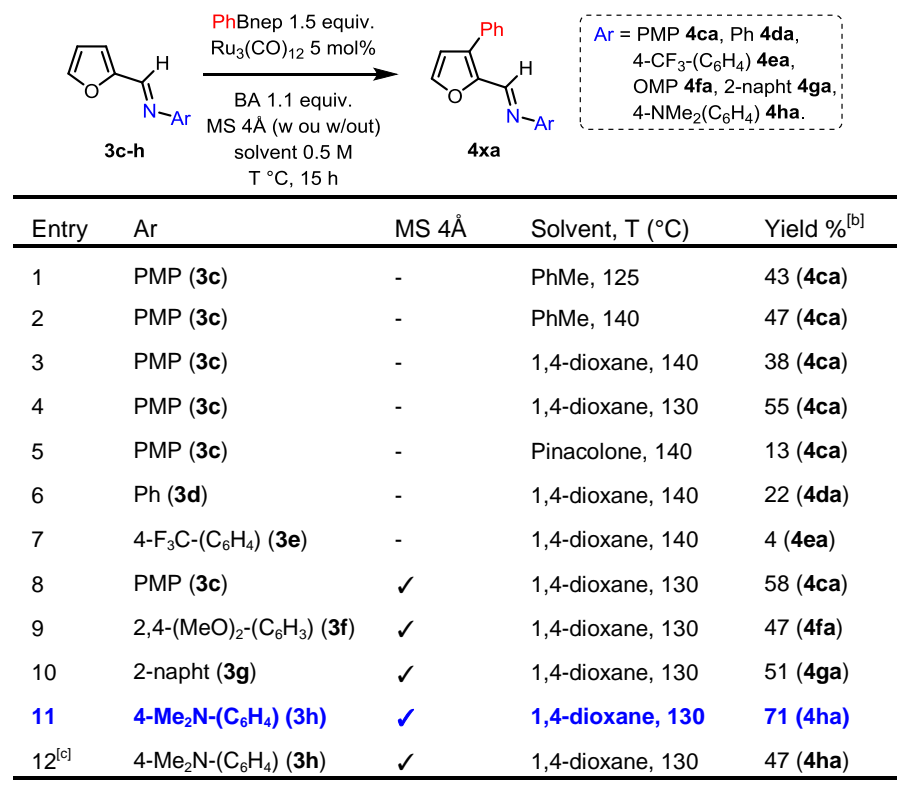

[a] Reaction conditions: $3 c-h(0.5 \mathrm{mmol}), \mathrm{PhBnep}(0.75 \mathrm{mmol}), \mathrm{Ru}_{3}(\mathrm{CO})_{12}$ $(0.025 \mathrm{mmol}), \mathrm{BA}(0,55 \mathrm{mmol}), \mathrm{MS} 4 \AA$ ( $270 \mathrm{mg})$, solvent $(1 \mathrm{~mL})$. [b] ${ }^{1} \mathrm{H}-\mathrm{NMR}$ yield of corresponding phenylated imines 4xa, determined using 1,3,5 trimethoxybenzene as internal standard. [c] 1.5 equiv. of $\mathrm{MgSO}_{4}$ instead of $\mathrm{MS}$ $4 \AA$. PMP $=p$-methoxyphenyl.

The nature of the imine was considered next. The use of the phenyl-imine $\mathbf{3 d}$ or the electron-poor aromatic imine $\mathbf{3 e}$ led to a clear reactivity drop (compare entries 3 and 6-7), and the encouraging result of the electron-rich aromatic imine $3 c$ (entry 4) could be further improved by addition of $4 \AA$ molecular sieves (MS) (entry 8). Additional electron-rich aromatic imines (3f-h) were next tested (entries 9-11). In the event, use of $p$ dimethylaminophenyl-imine (PDMAPh-imine) $\mathbf{3 h}$ afforded the desired $\mathrm{C}-\mathrm{H}$ arylation product 4 ha with the highest NMR yield $(71 \%)$. Finally, the use of $\mathrm{MgSO}_{4}$ instead of $\mathrm{MS}$ gave a modest result (entry 12). ${ }^{[20]}$ The sensitivity of the reaction to the electron richness of the aldimine nitrogen atom is evident and suggests that increase of basicity of the nitrogen atom is key. Indeed, the para-located electron-donors of the best-behaved imines $3 \mathrm{c}$ and 3h compete with the nitrogen atom in lone pair delocalization into the aromatic ring, rendering the aldimine nitrogen atom more basic via an arylogous alpha-effect. We speculate that such enhanced basicity of the nitrogen atom may favor nitrogen coordination to ruthenium throughout the catalytic cycle (vide infra the proposed mechanism).

With the optimal conditions in hand (entry 11), the scope of this $\mathrm{C}-\mathrm{H}$ arylation between PDMAPh-imine $\mathbf{3 h}$ and various arylboronic acids neopentylglycol esters ArBnep was investigated. Direct isolation of the $\mathrm{C}-\mathrm{H}$ arylated products in the form of the corresponding aldehydes, although initially attempted, was unsuccessful. However, acid hydrolysis of the arylated-imine $\mathbf{4 h y}{ }^{[19]}$ after a rapid silica gel chromatographic purification took place uneventfully. ${ }^{[21]}$ First, we reacted imine $\mathbf{3 h}$ with a variety of ArBnep bearing para or meta located electronwithdrawing or -donating groups, as well as with a 2-thienyl boronate derivatives. In all the cases, arylated-imines 4 hy were obtained with moderate yields $(47-57 \%$ isolated yields after chromatography or $52-76 \%$ NMR yields, see SI) (Scheme 3, top). The subsequent acid hydrolysis enabled access to the arylatedfurfurals $5 \mathrm{y}$ with very good yields.

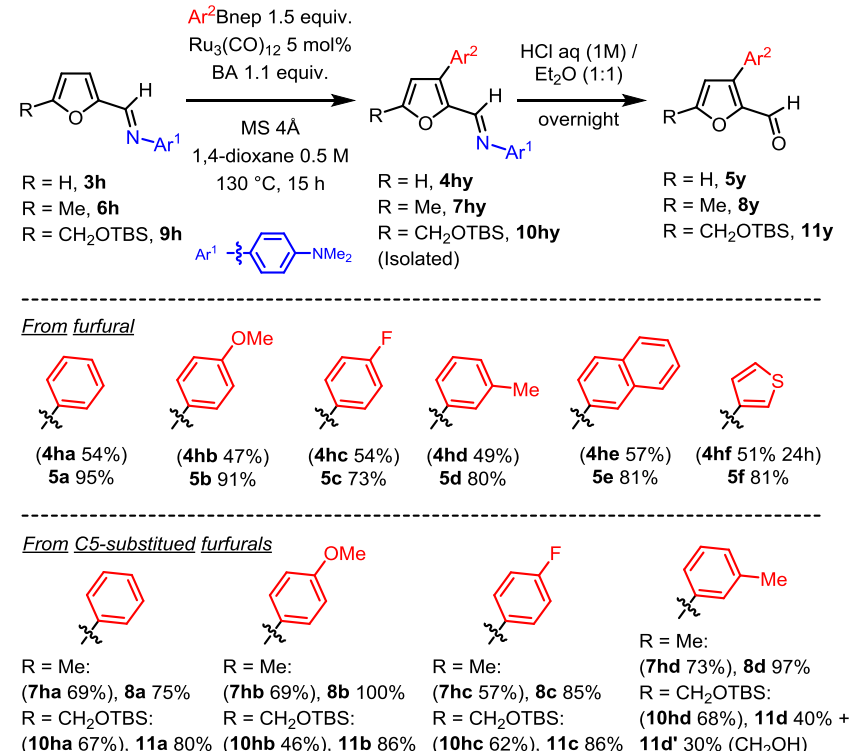

(10hb $46 \%)$, 11b $86 \%$ (10hc $62 \%), 11$ c $86 \%$, 11 d' $30 \%\left(\mathrm{CH}_{2} \mathrm{OH}\right)$

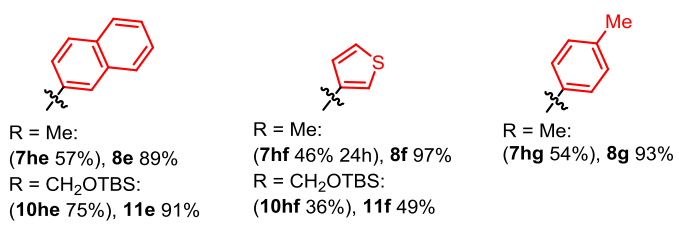

Scheme 3. Scope of Ru-catalyzed C3-arylation. ${ }^{22}$

The scope of the study was next extended to C5 substituted furfural-imines, such as 5-methylfurfural-imine $6 \mathrm{~h}$ and the TBSprotected HMF imine 9h (readily prepared from HMF 2 see SI) (Scheme 3, bottom rows). With these two starting materials, various arylboronic neopentylglycol esters bearing electron-rich and electron-poor functional groups in para or meta position also afforded the desired arylated-imines (7hy or 10hy respectively) in reasonable to good yields. However, coupling of 2- 
$\mathrm{MeC}_{6} \mathrm{H}_{4}$ Bnep was inefficient, very likely due to the steric hindrance of the boronate partner. The C3-arylated furfurals were isolated with excellent yields after mild hydrolysis, except for the TBS protected furfural-imines 10hd and 10hf, which suffered partial deprotection of the TBS group (10hd) or degradation (10hf). Additionally, a double coupling was successfully achieved with the HMF-dimer diimine $\mathbf{1 2 h}$ and two equivalents of PhBnep, which gave the di-phenylated HMF imine dimer 13ha and the corresponding dialdehyde 14a after hydrolysis (Scheme 4).

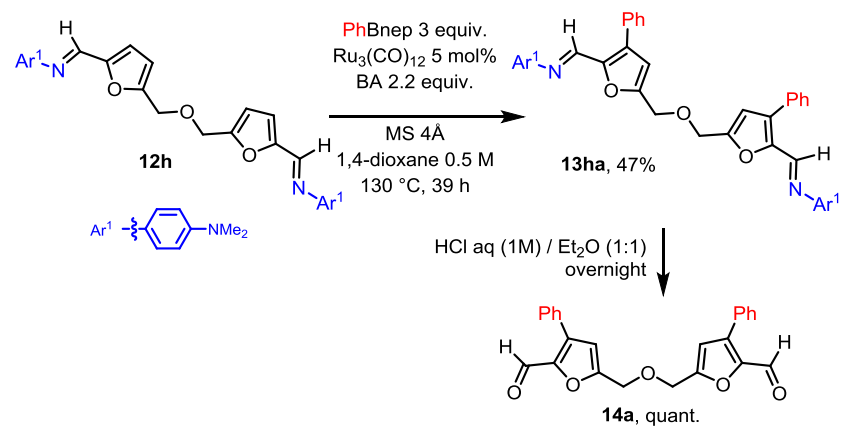

Scheme 4. Ru-catalyzed C3-phenylation of HMF-dimer derivative.

Then, the scope of the reaction was studied with an alkenylboronate derivative, namely cinnamylboronic neopentylglycol ester. This boronate partner proved to be effective, and furfural-imines $3 \mathrm{~h}$ and $\mathbf{6 h}$ gave the desired alkenylated imine derivatives 15 (48\%) and 16 (68\%), which were successfully hydrolyzed to the corresponding alkenylated furfurals 17 (88\%) and 18 (quant.) (Scheme 5).

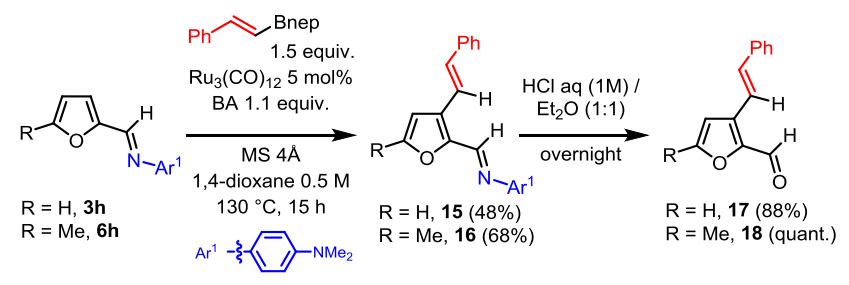

Scheme 5. Ru-catalyzed C3-alkenylation of furfural-imines.

Other synthetic applications of the C3-arylated furfurylimines were then evaluated (Scheme 6). ${ }^{[18]}$ First, treatment of imines 4ha and 7 ha with $\mathrm{NaBH}_{4}$ in presence of $\mathrm{TsOH}$ gave the corresponding furfural-amines 19 and 20 in moderate to good yields. Furthermore, treatment of 4 ha with $n$-BuLi gave smoothly the alkylated amine 21.

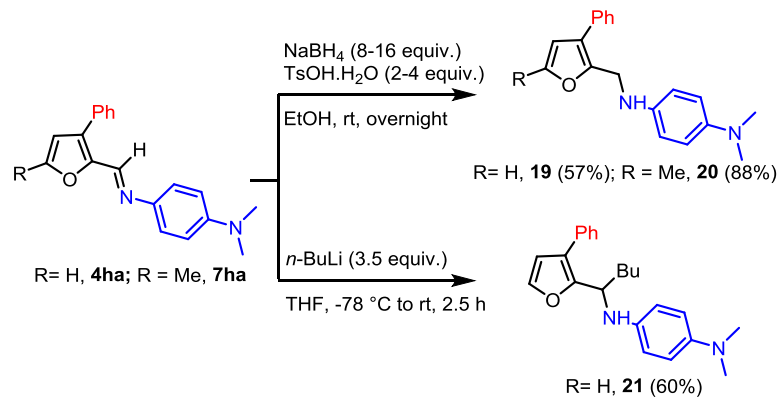

Scheme 6. Synthetic applications.

A plausible mechanism for this Ru-catalyzed C3-arylation ${ }^{[15 b]}$ is presented in Scheme 7 for the reaction between PDMAPhimine 3h and PhBnep. By analogy with our previous study, ${ }^{[13]}$ we anticipate the initial decarbonylative $\mathrm{Ru}-\mathrm{Ru}$ cleavage of $\mathrm{Ru}_{3}(\mathrm{CO})_{12}$ pre-catalyst to generate the mononuclear complex $\mathrm{Ru}(0)(\mathrm{CO})_{3}{ }^{[23]}$ and coordination by PDMAPh-imine $\mathbf{3 h}$ affords complex A. Oxidative addition of the $\mathrm{C} 3-\mathrm{H}$ furfural position likely through agostic $\mathrm{C} 3-\mathrm{H} / \mathrm{Ru}(0)$ interaction - takes then place, to form the $\mathrm{Ru}(\mathrm{II})-\mathrm{H}$ species $\mathrm{B}$. Subsequent 1,4-addition of the ruthenium hydride to benzylideneacetone (BA) gives the

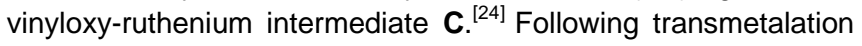
between PhBnep and the alkoxy-ruthenium complex $\mathbf{C}$ results in the formation of furfuryl-phenyl ruthenium intermediate $\mathbf{E}$ and the boryl enol ether $\mathbf{D}$. Finally, reductive elimination from $\mathbf{E}$ followed by a trans-imination in the presence of a new molecule of starting furylimine $3 \mathrm{~h}$ releases product $4 \mathrm{ha}$ and regenerates catalyst A. The boryl enol ether $\mathbf{D}$ is hydrolyzed to 4phenylbutan-2-one during the work-up, as detected in the ${ }^{1} \mathrm{H}$ NMR of the crude product.

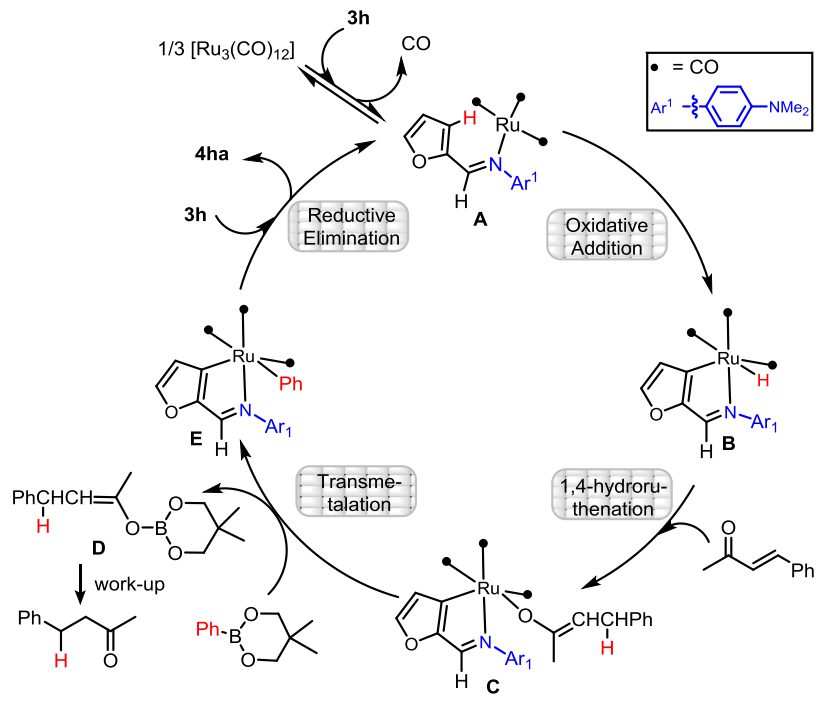

Scheme 7. Proposed mechanism of the catalytic cycle.

\section{Conclusions}


In summary, we have developed the directed C3-arylation of furfural imines with arylboronic acid neopentylglycol esters, under Ru-catalysis. This straightforward $\mathrm{C}-\mathrm{H}$ functionalization method requires the use of electron-rich aromatic imines, such as a $p$-dimethylaminophenyl-imine. When using cinnamylboronic neopentylglycol ester, the same catalytic system promotes C3cinnamylation. The mild acid hydrolysis enables access to arylated- or cinnamylated-furfural derivatives. Further work is ongoing to demonstrate the synthetic value of the new C3 functionalized furfurals by accessing relevant target molecules of synthetic, industrial and / or biological value.

\section{Experimental Section}

All experimental procedures and compound characterizations are described in Supporting Information available online.

General procedure for Ru-catalyzed arylation or alkenylation of furfural imines. In a sealed tube, a solution of $\mathrm{Ru}_{3}(\mathrm{CO})_{12}(0.025 \mathrm{mmol}, 5$ mol\%), furfural imine ( $0.5 \mathrm{mmol}, 1.0$ equiv.), aryl- or cinnamyl-boronic acid neopentylglycol ester ( $0.75 \mathrm{mmol}, 1.5$ equiv.), benzylideneacetone (BA) $(0.55 \mathrm{mmol}, 1.1$ equiv.) and molecular sieves $4 \AA$ (typically, $264 \mathrm{mg}$ ) in 1,4-dioxane $(0.5 \mathrm{M})$ was stirred for $15 \mathrm{~h}$ at $130^{\circ} \mathrm{C}$. The reaction mixture was let cool to room temperature, diluted with $\mathrm{CH}_{2} \mathrm{Cl}_{2}$ and filtered through Celite. The solvent was removed and the crude product was purified by silica gel chromatography affording the corresponding C3functionnalized products.

\section{(E)-N,N-dimethyl-4-(((3-phenylfuran-2-yl)methylene)amino)aniline}

(4ha): Prepared according to general procedure from $(E)-4$-((furan-2ylmethylene)amino)-N,N-dimethylaniline $3 \mathrm{~h}$ (107.1 mg, $0.5 \mathrm{mmol}), 5,5$ dimethyl-2-phenyl-1,3,2-dioxaborinane a (142.5 $\mathrm{mg}, 0.75 \mathrm{mmol})$, benzylideneacetone $(80.4 \mathrm{mg}, 0.55 \mathrm{mmol}), \mathrm{Ru}_{3}(\mathrm{CO})_{12}(16.0 \mathrm{mg}, 0.025$ mmol), molecular sieves $4 \AA$ (264 mg). The crude product $(71 \%$ NMR yield) was purified by flash chromatography on silica gel eluting with CyHex/EtOAc (80/20) to afford $78.7 \mathrm{mg}$ of $\mathbf{4 h a}(54 \%$ yield) as a brown solid. m.p. $92{ }^{\circ} \mathrm{C} .{ }^{1} \mathbf{H}$ NMR (300 MHz, $\left.\mathbf{C D C l}_{3}\right) \delta 8.47$ (s, $\left.1 \mathrm{H}\right), 7.63$ (dd, J= $1.8,0.5 \mathrm{~Hz}, 1 \mathrm{H}), 7.51-7.43(\mathrm{~m}, 5 \mathrm{H}), 7.32-7.28(\mathrm{~m}, 2 \mathrm{H}), 6.75(\mathrm{~d}, J=9.0$ $\mathrm{Hz}, 2 \mathrm{H}), 6.70$ (d, J=1.8 Hz, $1 \mathrm{H}), 3.00$ (s, 6H). ${ }^{13} \mathbf{C}$ NMR (75 MHz, $\mathbf{C D C l}_{3}$ ) ठ 149.8, 147.7, 144.7, 142.8, 140.7, 132.6, 131.9, 129.0, 128.9, 128.1, 122.6, 113.2, 112.9, 40.8. IR ( $\left.\mathbf{c m}^{-1}\right) \vee 3139,2922,2854,1670,1590$, 1512, 1443, 1359, 1227, 1059, 759. HRMS m/z calculated for $\mathrm{C}_{19} \mathrm{H}_{19} \mathrm{~N}_{2} \mathrm{O}$ $[\mathrm{M}+\mathrm{H}]^{+}:$291.1492; found 291.1500 .

\section{(E)-4-((3-(4-methoxyphenyl)furan-2-yl)methylene)amino)-N,N-}

dimethylaniline (4hb): Prepared according to general procedure from (E)-4-((furan-2-ylmethylene)amino)-N,N-dimethylaniline $3 \mathrm{~h}$ (107.1 $\mathrm{mg}$, $0.5 \mathrm{mmol}), \quad 2$-(4-methoxyphenyl)-5,5-dimethyl-1,3,2-dioxaborinane b (165.1 mg, $0.75 \mathrm{mmol}$, ), benzylideneacetone (80.4 mg, $0.55 \mathrm{mmol}$ ), $\mathrm{Ru}_{3}(\mathrm{CO})_{12}(16.0 \mathrm{mg}, 0.025 \mathrm{mmol})$, molecular sieves $4 \AA(275 \mathrm{mg})$. The crude product ( $58 \%$ NMR yield) was purified by flash chromatography on silica gel eluting with CyHex/EtOAc (80/20) to afford $75.9 \mathrm{mg}$ of $\mathbf{4 h b}$ (47\% yield) as a brown solid. m.p. $112^{\circ} \mathrm{C} .{ }^{1} \mathbf{H}$ NMR $\left(300 \mathbf{~ M H z}, \mathbf{C D C l}_{3}\right) \delta$ $8.33(\mathrm{~s}, 1 \mathrm{H}), 7.49-7.48(\mathrm{~m}, 1 \mathrm{H}), 7.32(\mathrm{~d}, J=8.8 \mathrm{~Hz}, 2 \mathrm{H}), 7.18(\mathrm{~d}, J=9.2$ $\mathrm{Hz}, 2 \mathrm{H}), 6.88$ (d, $J=8.8 \mathrm{~Hz}, 2 \mathrm{H}), 6.63(\mathrm{~d}, J=9.1 \mathrm{~Hz}, 2 \mathrm{H}), 6.53(\mathrm{~d}, J=1.8$ $\mathrm{Hz}, 1 \mathrm{H}), 3.75$ (s, 3H), 2.87 (s, 6H). ${ }^{13} \mathbf{C}$ NMR (75 MHz, CDCl $)_{3} \delta 159.6$, $149.6,147.2$, 144.6, 142.9, 140.7, 131.6, 129.9, 124.8, 122.5, 114.4, 113.1, 112.8, 55.4, 40.7. IR ( $\left.\mathbf{c m}^{-1}\right) \vee 2960,2923,1663,1511,1439,1351$ 1244, 1061, 747. HRMS $\mathrm{m} / \mathrm{z}$ calculated for $\mathrm{C}_{20} \mathrm{H}_{21} \mathrm{~N}_{2} \mathrm{O}_{2}[\mathrm{M}+\mathrm{H}]^{+}$: 321.1598; found 321.1608.

(E)-4-(((5-)((tert-butyldimethylsilyl)oxy)methyl)-3-phenylfuran-2yl)methylene)amino)-N,N-dimethylaniline (10ha): Prepared according to general procedure from
butyldimethylsilyl)oxy)methyl)furan-2-ylmethylene)amino)-N,Ndimethylaniline 9 h (179.3 mg, 0.5 mmol), 5,5-dimethyl-2-phenyl-1,3,2 dioxaborinane a $(142.5 \mathrm{mg}, 0.75 \mathrm{mmol})$, benzylideneacetone $(80.4 \mathrm{mg}$, $0.55 \mathrm{mmol}), \mathrm{Ru}_{3}(\mathrm{CO})_{12}(16.0 \mathrm{mg}, 0.025 \mathrm{mmol})$, molecular sieves $4 \AA$ ( 274 $\mathrm{mg})$. The crude product (71\% NMR yield) was purified by flash chromatography on silica gel eluting with CyHex/EtOAc $(90 / 10)$ to afford $145.5 \mathrm{mg}$ of $\mathbf{1 0 h a}\left(67 \%\right.$ yield) as a brown solid. m.p. $88.0^{\circ} \mathrm{C}$. ${ }^{\mathbf{1}} \mathbf{H}$ NMR $\left(400 \mathrm{MHz}, \mathrm{CDCl}_{3}\right) \delta 8.24(\mathrm{~s}, 1 \mathrm{H}), 7.35-7.24(\mathrm{~m}, 5 \mathrm{H}), 7.11-7.98(\mathrm{~m}, 2 \mathrm{H})$, 6.58-6.56 (m, 2H), $6.41(\mathrm{~s}, 1 \mathrm{H}), 4.69(\mathrm{~s}, 2 \mathrm{H}), 2.81(\mathrm{~s}, 6 \mathrm{H}), 0.81(\mathrm{~s}, 9 \mathrm{H})$, 0.00 (s, 6H). ${ }^{13} \mathrm{C}$ NMR (101 MHz, $\left.\mathbf{C D C l}_{3}\right) \delta 157.8,149.6,146.7,143.1$ 140.9, 133.1, 132.7, 128.9, 128.0, 122.5, 112.9, 112.8, 109.7, 59.1, 40.8, $25.9,18.5,-5.2$. IR $\left(\mathrm{cm}^{-1}\right)$ v 3051, 2930, 2854, 1675, 1613, 1511, 1457, 1351, 1256, 1219, 1064, 841, 771. HRMS $\mathrm{m} / \mathrm{z}$ calculated for $\mathrm{C}_{26} \mathrm{H}_{35} \mathrm{~N}_{2} \mathrm{O}_{2} \mathrm{Si}[\mathrm{M}+\mathrm{H}]^{+}:$435.2462; found 435.2475.

(E)-4-(((5-)((tert-butyldimethylsilyl)oxy)methyl)-3-(4methoxyphenyl)furan-2-yl)methylene)amino)-N,N-dimethylaniline (10hb): Prepared according to general procedure from (E)-1-(5-(((tertbutyldimethylsilyl)oxy)methyl)furan-2-ylmethylene)amino)-N,N-

dimethylaniline $9 \mathrm{~h}$ (179.3 mg, $0.5 \mathrm{mmol}), 2$-(4-methoxyphenyl)-5,5dimethyl-1,3,2-dioxaborinane b $(165.1 \quad \mathrm{mg}, 0.75 \mathrm{mmol})$ benzylideneacetone $(80.4 \mathrm{mg}, 0.55 \mathrm{mmol}), \mathrm{Ru}_{3}(\mathrm{CO})_{12}(16.0 \mathrm{mg}, 0.025$ $\mathrm{mmol})$, molecular sieves $4 \AA$ (266 mg). The crude product $(73 \%$ NMR yield) was purified by flash chromatography on silica gel eluting with CyHex/EtOAc (90/10) to afford $106.0 \mathrm{mg}$ of $10 \mathrm{hb}$ (46\% yield) as a brown solid. m.p. $107.9^{\circ} \mathrm{C} .{ }^{1} \mathbf{H}$ NMR (400 $\mathbf{~ M H z , ~} \mathbf{C D C l}_{3}$ ) $\delta 8.22(\mathrm{~s}, 1 \mathrm{H}), 7.28$ (d, J $=8.7 \mathrm{~Hz}, 2 \mathrm{H}), 7.13-7.09(\mathrm{~m}, 2 \mathrm{H}), 6.84(\mathrm{~d}, J=8.8 \mathrm{~Hz}, 2 \mathrm{H}), 6.59(\mathrm{~d}, J=9.0$ $\mathrm{Hz}, 2 \mathrm{H}), 6.38-6.37(\mathrm{~m}, 1 \mathrm{H}), 4.69(\mathrm{~s}, 2 \mathrm{H}), 3.72(\mathrm{~s}, 3 \mathrm{H}), 2.83(\mathrm{~s}, 6 \mathrm{H}), 0.81$ $(\mathrm{s}, 9 \mathrm{H}),-0.00(\mathrm{~s}, 6 \mathrm{H}) .{ }^{13} \mathrm{C}$ NMR (101 MHz, $\left.\mathbf{C D C l}_{3}\right) \delta 159.7,157.8,149.6$, $146.4,143.4,141.3,133.0,130.1,125.1,122.5,114.5,112.9,109.7$, $59.2,55.5,40.9,26.0,18.6,-5.2$. IR $\left(\mathbf{c m}^{-1}\right) \vee 2956,2852,1668,1608$, 1507, 1457, 1352, 1249, 1075, 842, 774. HRMS m/z calculated for $\mathrm{C}_{27} \mathrm{H}_{37} \mathrm{~N}_{2} \mathrm{O}_{3} \mathrm{Si}[\mathrm{M}+\mathrm{H}]^{+}:$465.2568; found 465.2583.

General procedure for acid hydrolysis of C3-arylated or vinylated furfural imines. To a solution of C3-arylated or vinylated furfural imine $(0.05 \mathrm{mmol}, 1$ equiv.) in diethyl ether $(0.02 \mathrm{M})$ was added dropwise $\mathrm{HCl}$ (aq, $1 \mathrm{~N}, 2.5 \mathrm{~mL}$ ). The mixture was stirred overnight at room temperature and diluted with diethyl ether $(10 \mathrm{~mL})$. The aqueous layer was extracted with diethyl ether $(3 \times 20 \mathrm{~mL})$ and the organic layers were combined, dried over $\mathrm{MgSO}_{4}$, filtered and concentrated affording the corresponding C3-functionnalized furfural derivatives.

3-Phenylfuran-2-carbaldehyde (5a): Prepared according to general procedure from $\quad(\mathrm{E})-\mathrm{N}, \mathrm{N}$-dimethyl-4-(((3-phenylfuran-2$\mathrm{yl})$ methylene)amino)aniline $4 \mathrm{ha}(15.1 \mathrm{mg}, 0.05 \mathrm{mmol}) .8 .2 \mathrm{mg}$ of product 5a was obtained as a brown oil $\left(95 \%\right.$ yield). ${ }^{1} \mathbf{H}$ NMR $\left(300 \mathbf{~ M H z}, \mathbf{C D C l}_{3}\right) \delta$ $9.75(\mathrm{~s}, 1 \mathrm{H}), 7.70(\mathrm{dd}, J=1.7,0.8 \mathrm{~Hz}, 1 \mathrm{H}), 7.58-7.45(\mathrm{~m}, 5 \mathrm{H}), 6.74(\mathrm{~d}, J$ $=1.7 \mathrm{~Hz}, 1 \mathrm{H})$. The spectral data are in good agreement with those previously reported. ${ }^{[25]}$

3-(4-methoxyphenyl)furan-2-carbaldehyde (5b): Prepared according to general procedure from $(E)-4-(((3-(4-m e t h o x y p h e n y)) f u r a n-2-$ $\mathrm{yl}$ )methylene)amino)-N,N-dimethylaniline $\mathbf{4 h b}$ (12.0 mg, $0.04 \mathrm{mmol}) .6 .8$ $\mathrm{mg}$ of product $\mathbf{5 b}$ was obtained as a brown oil ( $90 \%$ yield). ${ }^{1} \mathbf{H}$ NMR (300 MHz, $\left.\mathbf{C D C l}_{3}\right) \delta 9.74(\mathrm{~s}, 1 \mathrm{H}), 7.67$ (d, $\left.J=2.2 \mathrm{~Hz}, 1 \mathrm{H}\right), 7.53$ (dd, $J=9.0$, $2.4 \mathrm{~Hz}, 2 \mathrm{H}), 7.02-6.97(\mathrm{~m}, 2 \mathrm{H}), 6.70(\mathrm{~d}, J=1.7 \mathrm{~Hz}, 1 \mathrm{H}), 3.87(\mathrm{~s}, 3 \mathrm{H}) .{ }^{13} \mathrm{C}$ NMR $\left(75 \mathbf{~ M H z}, \mathbf{C D C l}_{3}\right) \delta 178.0,160.7,147.6,147.5,138.6,130.5,122.9$, 114.6, 113.7, 55.6. IR $\left(\mathrm{cm}^{-1}\right) \vee 2959,2838,1762,1662,1512,1426$ $1365,1247,1028,768$. HRMS $\mathrm{m} / \mathrm{z}$ calculated for $\mathrm{C}_{12} \mathrm{H}_{11} \mathrm{O}_{3}[\mathrm{M}+\mathrm{H}]^{+}$: 203.0703; found 203.0702 .

5-(((tert-butyldimethylsilyl)oxy)methyl)-3-phenylfuran-2carbaldehyde (11a): Prepared according to general procedure from $(E)$ 4-(((5-(((tert-butyldimethylsilyl)oxy)methyl)-3-phenylfuran-2yl)methylene)amino)-N,N-dimethylaniline $10 \mathrm{ha}(21.7 \mathrm{mg}, 0.05 \mathrm{mmol}$ ). $12.7 \mathrm{mg}$ of product $11 \mathrm{a}$ was obtained as a brown oil ( $80 \%$ yield). ${ }^{1} \mathbf{H}$ NMR (400 MHz, $\left.\mathrm{CDCl}_{3}\right) \delta 9.68(\mathrm{~s}, 1 \mathrm{H}), 7.57-7.54(\mathrm{~m}, 2 \mathrm{H}), 7.47-7.45(\mathrm{~m}, 3 \mathrm{H})$, 
$6.61(\mathrm{~s}, 1 \mathrm{H}), 4.78(\mathrm{~s}, 2 \mathrm{H}), 0.94(\mathrm{~s}, 9 \mathrm{H}), 0.14(\mathrm{~s}, 6 \mathrm{H}) .{ }^{13} \mathrm{C}$ NMR (101 MHz, $\left.\mathrm{CDCl}_{3}\right) \delta 177.7,161.0,146.9,140.2,130.9,129.4,129.2,125.7,110.4$, 58.9, 25.9, 18.5, -5.2. IR $\left(\mathrm{cm}^{-1}\right) \vee 2928,2856,1768,1668,1538,1449$, $1357,1255,1089,765$. HRMS $\mathrm{m} / \mathrm{z}$ calculated for $\mathrm{C}_{18} \mathrm{H}_{25} \mathrm{O}_{3} \mathrm{Si}[\mathrm{M}+\mathrm{H}]^{+}$: 317.1567 ; found 317.1566 .

5-(((tert-butyldimethylsilyl)oxy)methyl)-3-(4-methoxyphenyl)furan-2carbaldehyde (11b): Prepared according to general procedure from $(E)$ 4-(((5-)((tert-butyldimethylsilyl)oxy)methyl)-3-(4-methoxyphenyl)furan-2$\mathrm{yl}$ )methylene)amino)- $\mathrm{N}, \mathrm{N}-$ dimethylaniline $10 \mathrm{hb}(23.6 \mathrm{mg}, 0.05 \mathrm{mmol})$. $15.1 \mathrm{mg}$ of product $\mathbf{1 1 b}$ was obtained as a brown oil ( $86 \%$ yield). ${ }^{1} \mathbf{H}$ NMR (400 MHz, $\mathrm{CDCl}_{3}$ ) ठ 9.67 (s, 1H), $7.52(\mathrm{~d}, J=8.8 \mathrm{~Hz}, 2 \mathrm{H}), 6.99$ (d, $J=$ $8.8 \mathrm{~Hz}, 2 \mathrm{H}), 6.57(\mathrm{~s}, 1 \mathrm{H}), 4.76(\mathrm{~s}, 2 \mathrm{H}), 3.86(\mathrm{~s}, 3 \mathrm{H}), 0.94(\mathrm{~s}, 9 \mathrm{H}), 0.13(\mathrm{~s}$, $6 \mathrm{H}) .{ }^{13} \mathrm{C}$ NMR $\left(101 \mathrm{MHz}, \mathrm{CDCl}_{3}\right) \delta 177.7,160.9,160.6,146.7,139.9$, $130.4,130.4,123.2,114.6,114.5,110.9,110.3,58.9,55.6,25.9,18.5$, 5.2. IR ( $\left.\mathrm{cm}^{-1}\right)$ v 2929, 2856, 1765, 1663, 1541, 1356, 1249, 1032, 777. HRMS $\mathrm{m} / \mathrm{z}$ calculated for $\mathrm{C}_{19} \mathrm{H}_{27} \mathrm{O}_{4} \mathrm{Si}[\mathrm{M}+\mathrm{H}]^{+}$: 347.1673; found 347.1669.

\section{Acknowledgements}

The authors would like to acknowledge Horizon 2020 ERANetLAC project CelluloseSynThech for financial support (ref. ELAC2014/BEE-0341), as well as CNRS, Sorbonne Université and Labex Michem (Investissements d'Avenir programme, ref. ANR-11-IDEX-0004-02) and Fundação para a Ciência e Tecnologia (SFRH/BPD/88666/2012). Support through CMST COST Action, CA15106 (CHAOS) and Dr. Svilen P. Simeonv for providing sample of $12 \mathrm{~h}$ is also gratefully acknowledged.

Keywords: C-H activation $\cdot$ ruthenium $\cdot$ furfurals $\cdot$ boronate derivatives $\bullet$ imines

[1] For recent books and reviews on $\mathrm{C}-\mathrm{H}$ bond functionalizations, see: a) J.-Q. Yu in Catalytic Transformations via C-H Activation, vols 1 and 2, Science of Synthesis, Thieme, 2016; b) T. Gensch, M. N. Hopkinson, F. Glorius, J. Wencel-Delord, Chem. Soc. Rev. 2016, 45, 2900; c) F Roudesly, J. Oble, G. Poli, J. Mol. Cat. A. 2017, 426, 275.

[2] a) A. Corma, S. Iborra, A. Velty, Chem. Rev. 2007, 107, 2411; b) J. J. Bozell, G. R. Petersen, Green Chem. 2010, 12, 539; c) C-H. Zhou, C-X Lin, D-S. Tong, J. Beltramini, Chem. Soc. Rev. 2011, 40, 5588; d) J. C. Serrano-Ruiz, R. Luque, A. Sepúlveda-Escribano, Chem. Soc. Rev 2011, 40, 5266; e) C. M. Cai, T. Zhang, R. Kumar, C. E. Wyman, J Chem. Technol. Biotechnol. 2014, 89, 2; f) J. S. Luterbacher, D. M. Alonso, J. A. Dumesic, Green Chem. 2014, 16, 4816; g) T. A. Bender, J. A. Dabrowski, M. R. Gagné, Nature Reviews Chemistry 2018, doi:10.1038/s41570-018-0005-y.

[3] a) H. E. Hoydonckx, W. M. Van Rhijn, W. Van Rhijn, D. E. De Vos, P. A. Jacobs in Furfural and derivatives. In Ullmann's Encyclopedia of Industrial Chemistry; Wiley-VCH Verlag GmbH \& Co. KgaA: Weinheim, Germany, 2000; Volume 16, pp. 285; b) R. Mariscal, P. Maireles-Torres, M. Ojeda, I. Sádaba, M. López Granados, Energy Environ. Sci. 2016, 9 , 1144 ; c) K. J. Zeitsch in The Chemistry and Technology of Furfural and its Many By-Products, Elsevier, Amsterdam, 2000.

[4] a) A. A. Rosatella, S. P. Simeonov, R. F. M. Frade, C. A. M. Afonso, Green Chem. 2011, 13, 754; b) E. Nikolla, Y. Román-Leshkov, M. Moliner, M. E. Davis, ACS Catal. 2011, 1, 408; c) R. J. van Putten, J. C. van der Waal, E. de Jong, C. B. Rasrendra, H. J. Heeres, J. G. de Vries, Chem. Rev. 2013, 113, 1499; d) I. K. M. Yu, D. C. W. Tsang Bioresour. Technol. 2017, 238, 716.

[5] From furfural, see: a) K. Yan, G. Wu, T. Lafleur, C. Jarvis, Renew. Sustain. Energy Rev. 2014, 38, 663; b) A. Bohre, S. Dutta, B. Saha, M.
M. Abu-Omar, M. M. ACS Sustain. Chem. Eng. 2015, 3, 1263; c) X. Li, P. Xia, T. Wang, ACS Catal. 2016, 6, 7621

[6] From HMF, see: a) B. Liu, Z. H. Zhang, ChemSusChem 2016, 9, 2015 b) K. Gupta, R. K. Rai, S. K. Singh, ChemCatChem 2018, DOI: 10.1002/cctc. 201701754

[7] C. Moreau, M. N. Belgacem, A. Gandini, A. Top. Catal. 2004, 27, 11.

[8] a) T. Itahara, M. Hashimoto, H. Yumisashi, Synthesis 1984, 255; b) T. Itahara, J. Org. Chem. 1985, 50, 5272; c) M. S. Mcclure, B. Glover, E. Mcsorley, A. Millar, M. H. Osterhout, F. Roschangar, Org. Lett. 2001, 3, 1677; d) M. Parisien, D. Valette, K. Fagnou, J. Org. Chem. 2005, 70, 7578; e) B. Liégault, D. Lapointe, L. Caron, A. Vlassova, K. Fagnou, J. Org. Chem. 2009, 74, 1826; f) D. Zhao, W. Wang, F. Yang, J. Lan, L. Yang, G. Gao, J. You, Angew. Chem. Int. Ed. 2009, 48, 3296; g) J. J. Dong, J. Roger, F. Požgan, H. Doucet, Green Chem. 2009, 11, 1832; h) P. Xi, F. Yang, S. Qin, D. Zhao, J. Lan, G. Gao, C. Hu, J. You, J. Am Chem. Soc. 2010, 132, 1822; i) N. A. B. Juwaini, J. K. P. Ng, J. Seayad, ACS Catal. 2012, 2, 1787; j) B. T. Luo, H. Liu, Z. J. Lin, J. Jiang, D. S Shen, R. Z. Liu, Z. Ke, F. S. Liu, Organometallics 2015, 34, 4881; j) A Jakab, Z. Dalicsek, T. Soós, Eur. J. Org. Chem. 2015, 56. k) Y. Cheng G. Li, Y. Liu, Y. Shi, G. Gao, D. Wu, J. Lan, J. You, J. Am. Chem. Soc. 2016, 138, 4730; k) N. Tsukada, T. Goto, H. Kato, Heterocycles, 2017 94, 2222.

[9] X. Jie, Y. Shang, P. Hu, W. Su, Angew. Chem. Int. Ed. 2013, 52, 3630.

[10] a) P. Hong, B.-R. Cho, H. Yamazaki, Chem. Lett. 1980, 507; b) T. Itahara, F. Ouseto, Synthesis 1984, 488; c) T. Itahara, J. Org. Chem. 1985, 50, 5546; d) Y. Shang, X. Jie, J. Zhou, P. Hu, S. Huang, W. Su Angew. Chem. Int. Ed. 2013, 52, 129.

[11] X. Jie, Y. Shang, P. Hu, W. Su, Angew. Chem. Int. Ed. 2013, 52, 3630.

[12] a) Y. Kuninobu, Y. Tokunaga, K. Takai, K. Chem. Lett. 2007, 36, 872 b) Y. Kuninobu, K. Kikuchi, Y. Tokunaga, Y. Nishina, K. Takai, K. Tetrahedron 2008, 64, 5974; c) L. Cuesta, T. Soler, E. P. Urriolabeitia Chem. Eur. J. 2012, 18, 15178; d) H. Wang, G. Wang, P. Li. P. Org. Chem. Front. 2017, 4, 1943.

[13] C. Pezzetta, L. F. Veiros, J. Oble, G. Poli, G. Chem. Eur. J. 2017, 23, 8385.

[14] For reviews on Ru-catalyzed $\mathrm{C}-\mathrm{H}$ functionalizations, see: a) $\mathrm{F}$ Kakiuchi, S. Murai, Acc. Chem. Res. 2002, 35, 826. b) P. Nareddy, F. Jordan, M. Szostak, M. ACS Catal. 2017, 7, 5721

[15] a) F. Kakiuchi, S. Kan, K. Igi, N. Chatani, S. Murai, S. J. Am. Chem. Soc. 2003, 125, 1698; b) F. Kakiuchi, Y. Matsuura, S. Kan, N. Chatani, J. Am. Chem. Soc. 2005, 127, 5936; c) S. Ueno, N. Chatani, F. Kakiuchi, J. Org. Chem. 2007, 72, 3600; d) S. Hiroshima, D Matsumura, T. Kochi, F. Kakiuchi, F. Org. Lett. 2010, 12, 5318; e) T. Yamamoto, T. Yamakawa, RSC Adv. 2015, 5, 105829

[16] Y. Zhao, V. Snieckus, Adv. Synth. Catal. 2014, 356, 1527.

[17] Y. Koseki, K. Kitazawa, M. Miyake, T. Kochi, F. Kakiuchi, F. J. Org Chem. 2017, 82, 6503.

[18] F. Hu, M. Szostak, Org. Lett. 2016, 18, 4186.

[19] In compounds $\mathbf{4 - 1 4} \mathbf{x y}, \mathbf{x}$ refers to the imine starting material and $\mathbf{y}$ refers to the aryl introduced.

[20] Use of other hydride acceptors (acetone, $(E)$-1,4-diphenylbut-2-en-1,4dione or $(E)$-chalcone), catalysts $\left(\mathrm{RuH}_{2}(\mathrm{CO})\left(\mathrm{PPh}_{3}\right)_{3}\right.$ or $\left.\mathrm{RhCl}\left(\mathrm{PPh}_{3}\right)_{3}\right)$ or boron partners (PhBPin, $\mathrm{PhB}(\mathrm{OH})_{2}, \mathrm{PhBF}_{3} \mathrm{~K}$ ) only gave very sluggish reactions or afforded complex mixtures.

[21] In a few cases, minor traces ( $5 \%)$ of imine hydrolysis occurred during chromatographic purification.

[22] All the C3-arylated imines were isolated by silica gel purifications. The aldehydes were obtained pure after the extraction step, except for rare cases (see SI).

[23] J. A. Cabeza, P. García-Álvarez, Chem. Soc. Rev. 2011, 40, 5389

[24] a) B. Martín-Matute, K. Bogár, M. Edin, F. B. Kaynak, J-E. Bäckvall, Chem. Eur. J. 2005, 11, 5832. b) C. Bianchini, E. Farnetti, M. Graziani, M. Peruzzini, A. Polo, Organometallics, 1993, 12, 3753.

[25] R. Antonioletti, M. D'Auria, A. De Mico, G. Piancatelli, A. Scettri, J. Chem. Soc., Perkin Trans. 1 1985, 1285. 


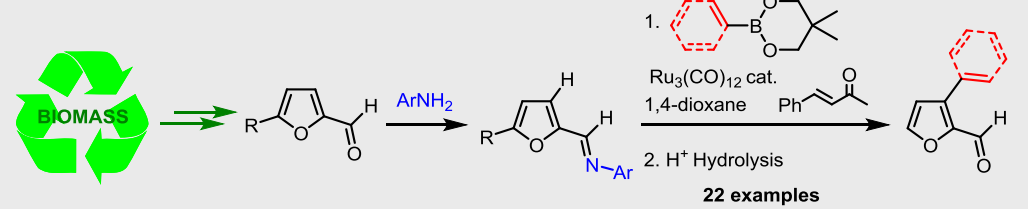

Furfural activated again: a Ru-catalyzed arylation and alkenylation of furfural imines with aryl- or alkenyl-boronates, involving a directed $\mathrm{C}-\mathrm{H}$ activation occurring at $\mathrm{C} 3$ of the furan ring, was developed. A thorough experimental study revealed that an electron-rich aromatic imine, such as a $p$-dimethylaminophenyl-imine, enables the coupling with good yields. After the coupling, a smooth hydrolytic removal of the imine directing-group releases the C3-functionalized furfurals.

\section{C-H activation}

Filipa Siopa, Valérie-Anne Ramis Cladera, Carlos Alberto Mateus Afonso, Julie Oble, * and Giovanni Poli*

Page No. - Page No.

Ruthenium-Catalyzed C-H Arylation and Alkenylation of Furfural

Derivatives 